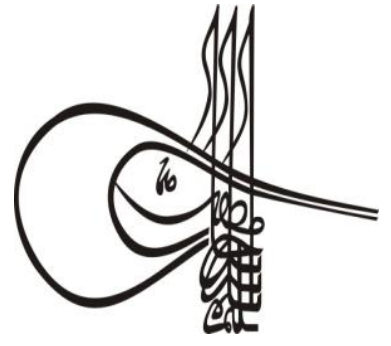

Received/Geliş: 24.06 .2019

\section{Turkigh Studies \\ Social Sciences}

Volume 14 Issue 4, 2019, p. 1637-1656

DOI: 10.29228/TurkishStudies.23395

ISSN: 2667-5617

Skopje/MACEDONIA-Ankara/TURKEY

Research Article / Araştırma Makalesi

Article Info/Makale Bilgisi

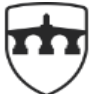

INTERNATIONAL BALKAN UNIVERSITY

EXCELLENCE FOR THE FUTURE IBU.EDU.MK

an Report Dates/Rapor Tarihleri: Referee 1 (22.07.2019)-Referee 2 (29.07.2019)

This article was checked by iThenticate.

\title{
TÜRK BANKACILIK SEKTÖRÜNDE SORUNLU KREDİLERİ BELİRLEYEN DEĞİŞKENLERİN ANALİZİ
}

\author{
Serdar KUZU* - İsmail Erkan ÇELİK**
}

\begin{abstract}
ÖZET
Ticari bankaların var olma sebeplerinden biri olan kredi verme işlemi ekonomik işleyiş açısından büyük önem arz etmektedir. Fakat bankaların verdikleri kredilerin geri ödenmemesi sonucunda hem mali hem de reel sektör ve bunun yanından ülke ekonomisi olumsuz bir şekilde etkilenebilmektedir. Geçmişte yaşanan kriz sonucunda görülen banka iflaslarının hem ülke hem de dünya ekonomisine çok büyük maliyetleri olmuştur. Özellikle günümüzde Türkiye'de etkisini gösteren ekonomik durgunluğun temel nedenlerinden biri geri dönmeyen sorunlu kredilerden kaynaklandığ 1 ifade edilebilir. $\mathrm{Bu}$ noktadan hareketle özellikle sorunlu kredilerin tespiti, seyri ve buna neden olabilecek hem makro hem de mikro değisskenlerin neler olabileceği hususunun ortaya konması sorunun tespiti açısından faydalı bilgiler sağlayacaktır. Bu çalışmada 2008-2018 yılları arasında 25 ticari bankanın sorunlu kredilerine neden olabilecek hem bankaya özgü hem de makroekonomik değişkenler ile bunlar arasında anlamlı bir ilişkinin olup olmadığı panel veri analizi yöntemi ile ortaya koyulacaktır. Çalışmanın amacı ülke ekonomilerin dinamosu olan bankaların sağl1klı bir şekilde faaliyetlerini sürdürmesinin temelini oluşturan sorunlu kredilerin makroekonomik değişkenler üzerinde ilişki derecesini analiz ederek, hangi değişkenin sorunlu krediler üzerinde etkileşim içinde olduğunu ve bu değişkenlerin sorunlu kredileri ne yönde etkilediğini ortaya koyarak literatüre katkı sağlanması amaçlanmaktadır. Bunun yanında çalışmanın daha önceki çalışmalarda sorunlu krediler ile ilişkili olabilecek bu kadar değişkenin ele alındığı çalışmanın olmayışı çalışmanın özgünlüğünü ortaya koymaktadır.
\end{abstract}

Dr. Öğr. Üyesi, İstanbul Üniversitesi, E-posta: serdarkuzuu @ hotmail.com 
Anahtar Kelimeler: Sorunlu Krediler, Panel Veri Analizi, Türk Bankac1lık Sektörü

Jel Siniflandirmasi: D53, G39, C22, E44

\title{
ANALYSIS OF VARIABLES DETERMINING NON-PERFORMING LOANS IN TURKISH BANKING SECTOR
}

\begin{abstract}
Lending, which is one of the reasons for the existence of Turkish banks, is of great importance in terms of economic functioning. However, as a result of the non-repayment of the loans granted by the banks, both the financial and real sectors, as well as the national economy, may be adversely affected. The bankruptcies seen as a result of the crisis in the past have had huge costs for both the country and the world economy. It can be stated that one of the main reasons of the economic stagnation, which has an impact in our country especially today, is the non-performing loans. In this study, panel data analysis method will be used to determine whether there is a significant relationship between the bank-specific and macroeconomic variables that may cause non-performing loans of 25 commercial banks between 2008-2018. The aim of this study is to analyze the degree of relationship of non-performing loans on macroeconomic variables, which is the basis of banks' dynamism of national economies, and to determine which variables interact on non-performing loans and how these variables affect non-performing loans. When the earlier studies of the study are examined, the lack of a study that deals with such variables that may be related to non-performing loans reveals the originality of the study.
\end{abstract}

\section{STRUCTURED ABSTRACT}

Aim: The aim of this study is to analyze the degree of relationship of problematic loans on macroeconomic variables, which is the basis of banks' dynamism of national economies, and to determine which variables interact on problematic loans and how these variables affect problematic loans. When the previous studies of the study are examined, the lack of a study that deals with such variables that may be related to non-performing loans reveals the originality of the study.

Method(s): The panel data model is estimated using the Pooled OLS, Fixed Effects and Random Effects approaches. In cases where the unit and time effects are homogeneous, if the error term does not include both effects, the HEKK Method gives effective and consistent estimators. If the approach and slope parameters vary between horizontal sections and the units in the sample are randomly selected, Random Effects (RE) approach is used. Assuming the stable relationship between nonperforming loans and other variables, the most appropriate method was Pooled Least Squares (HEKK - Pooled OLS, Classic Model) method. The use of horizontal cross-section and time series in panel data analysis method brings various problems. 
Therefore, cross-sectional dependence (correlation of error term between units) and unit root presence problems encountered in time series should be considered. Im, Peseran, Shin (2003) unit root test will be used for the problem of presence of unit root in time series for horizontal cross-sectional dependence.

Unit root tests in panel data analysis; individual unit root tests Im, Peseran, Shin (2003) (IPS) and Levin, Lin, Chu (2002) (LLC) are tested with common unit root tests. Both tests were used in this study. After determining that the variables are stationary in the relevant model, panel results of the Pooled Least Squares (HEKK - Pooled OLS, Classic Model) model are given in Table 5. Firstly, the model should be tested for autocorrelation and homoscedastic (constant variance) poroblems. Durbin-Watson (D-W Ist.) And Baltagi-Wu LBI tests were used for the autocorrelation test and the test results are given below.

Findings: The GDP parameter, which is the symbol of economic growth in the country, is observed to have an inverse relationship with non-performing loans. In addition, the exchange rate basket, interest rates and non-performing loans positively correlated. In other words, the possible increase in the exchange rate will have a positive effect on the economic growth as it will encourage import-deterrent exports. The increase in interest rates during the inflationary periods will increase both the reluctance to use loans and the problems related to the return of the loans given by the banks as a result of the deterioration in the economy will lead to the increase of non-performing loans.

When the findings obtained from the study were analyzed, it was observed that the relationship between the first delay of the real interest rate and non-performing loans was positive, and since the increase in the real interest rate increased the cost of credit, it caused difficulties in loan repayments and increased the problematic credits in this.

When the relationship between non-performing loans and the ratio of non-performing loans. This ratio is very important for banks and it also indicates the credit growth rate. When the relationship between the unemployment rate and non-performing loans is examined, it is observed that this relationship is positive. This situation has been observed, especially because of the unemployment rate.

When the relationship between the consumer loans and nonperforming loans is examined, it is observed that this relationship is positive. The large share of consumer loans reveals the importance of this variable. This situation gives meaningful results in terms of reflecting the current conjuncture structure. The increase in consumer loans will increase as well as the risk of repayment of existing loans.

When the relationship between the inflation rate and nonperforming loans is analyzed, it is observed that this relationship is positive. This situation causes problems, especially in the return of loans. When the relationship between the BIST 100 index, which rapidly reflects the positive and negative developments in the Bank's asset and the country, the direction and the degree of non-performing loans, this relationship degree is negative. This situation indicates that the BIST 100 index may have an effect on non-performing loans. 
Conclusion: As a result of panel data analysis, Real Effective Interest Rate, Asset Size, Share of Turkish Lira Loans, Deposit Conversion Rate, Capital Adequacy Ratio, Credit Growth Rate, Consumer Loans Share, Gross Domestic Product (GDP), Real Exchange Rate (RDK), Commercial Loan Interest Rate (FO), Borsa İstanbul-100 (BIST) index, Interbank Overnight Average Interest Rate, inflation, monetary aggregate, exchange rate basket and unemployment rate and the relationship between non-performing loans were statistically significant.

When the previous literature studies of the study are examined, the lack of a study that deals with such variables that may be related to non-performing loans reveals the originality of the study.

Keywords: Non-performing Loans, Panel Data Analysis, Turkish Banking Sector

JEL Classification: D53, G39, C22, E44

\section{Giriş}

Ticari bankalar günümüzde finansal piyasaların işleyişi üzerinde en önemli oyunculardan biri konumunda yer almaktadırlar. Özellikle ticari bankalar ekonomiye farklı düzeylerde yararlar sağlamasının yanında birtakım dinamikler kazandırmaktadır. Bu dinamikler arasında en önemli kısmı krediler kısmı oluşturmaktadır. Bankaların temel işlevlerinden biri mevduat toplamak ve bu mevduatları kredi olarak vermeleridir. Fakat ticari bankalar bu işlevi yerine getirirken karşı karşıya oldukları kredi riskini bertaraf edememekte ve sorunlu krediler ile karşı karşıya kalmaktadırlar.

Bankalar kredi kısmını farklı yollar ile karşılamalarına rağmen en önemli kısım tasarruf sahiplerinin bankaya ödünç olarak verdiği kısımdan karşılanmaktadır. Bankalar ödünç olarak aldıkları tasarrufları hem koruyabilme hem de maksimum kar getirebilecek şekilde kullanma çabası içindedirler. Ancak karlarını maksimize etme çabası içine girdiklerinde karşı karşıya kalabilecekleri en muhtemel sorun kullanılan kredilerin vadesinde geri ödenememesi bir başka ifadeyle kredilerin sorunlu hale gelmesidir.

Bankacılık sektöründe olası kayıplara neden olabilecek sorunlu kredilerin tespiti ve bunları etkileyen değişkenlerin belirlenmesi bankaların daha sağlıklı sermaye gereksinimi belirlemesi, kredi riskinin belirlenmesi, kredi portföyünün sağlıklı bir şekilde yönetilmesi ve buna göre gelecekte alacakları kararları şekillendirmesi açısından oldukça büyük öneme sahiptir.

Sorunlu kredilere ya da sorunlu kredilerin artışına neden olan faktörlerin belirlenememesi ve gerekli önlemlerin alınamaması sonucunda geçmişte de örneklerini yaşadığımız bankacılık krizleri ile karşılaşılması yadsınamaz bir gerçek olarak karşımıza çıkmaktadır. Bankacılık sektörünün var olma nedeni ve en temel görevlerinden biri kredi vermektir. Bu tür işlemler ağırlıklı olarak ticari bankalar aracılığı ile sağlanmaktadır. Bundan dolayı sorunlu kredilerde yaşanabilecek bir artış öncelikle ticari bankaları daha kırılgan hale getirmektedir.

Bu noktada ortaya çıkan bir durum ise finansal kırılganlık hususudur. Literatürde farklı olarak ifade edilen Finansal kırılganlık genel anlamda dış borçlarını operasyonel maliyetler üzerinde kullanan bir başka ifadeyle yüksek cari açık yâda gittikçe artan cari açık nedeniyle yabancı sermaye akımlarına daha bağımlı hale gelinmesi olarak ifade edilmektedir. (Stanley, 2013) 


\section{Sorunlu Krediler ve Sorunlu Kredilerin Bankacılık Sektörüne Etkileri}

Sorunlu krediler genel anlamda borçlu ile banka arasında gerçekleşen ödeme anlaşmasının bir şekilde bozulması, ödemenin gecikmesi ve bunun sonucunda zarar ihtimalinin ortaya çıkması olarak ifade edilmektedir. (Yahaya \& Oni, 2016) Burada dikkat edilmesi gereken husus ödemenin vadesinde yapılamaması ya da kısa vadede gecikmesi krediyi sorunlu hale getirmemektedir. Kredinin sorunlu hale gelebilmesi için ödemenin ya da borç anlaşmasının önemli derecede bozulup tahsilatın gecikmesi veyahut yapılamaması gerekmektedir. Burada ortaya çıkan gecikme süresi kredinin türüne göre farkl1lik arz etmektedir.

Sorunlu kredilerin uluslararası bağlamında ele alındığında, bir varlık ya da kredinin sorunlu varlık olarak nitelendirilebilmesi için kredinin anapara ve faizinin sözleşmede belirlenen gün süresinin 90 gün üzerinde olması ve ödemesi 90 günü aşan geciken faizlerin aktifleştirilmesi ya da yeniden yapılandırılması olarak ifade edilebilir (IMF, 2010).

Kredilerin sorunlu kredi haline gelmesi Basel II de yer alan bankanın kredi tahsis süresince teminat aldığı varsayımı altında, almış olduğu teminatı nakde çevirmeden, borçlunun bankaya olan kredi borcunu ödeme ihtimalinin olmadığına kanaat getirilmesi durumunda ya da bankanın kredi tahsis süresince teminat aldığ varsayımı altında, almış olduğu teminatı nakde çevirmeden, borçlunun bankaya olan kredi borcunu ödeme ihtimalinin olmadığına kanaat getirilmesi durumlarından bir ya da her ikisinin de gerçeklemesi durumunda vuku bulacağı ifade edilmektedir (BBDK, 2007).

Sorunlu krediler bankaların finansal zorluklara girme ihtimalini arttırdığı ve bankaların ekonomik açıdan istenen kar rakamlarına ulaşabilmeleri için sorunlu kredileri azaltmak zorundadır. Bankaların sorunlu krediler ila karşı karşıya kalmalarına neden olan bir diğer gelişme ise vade uyumsuzluğu sorunudur. Bu sorun kendini bankanın varlık ve yükümlülükleri arasında yaşanan vade sorunundan kaynaklanmaktadır. Burada en temel sorun bankaların uzun vadeli kredi verme isteklerinin yanında topladıkları mevduatların genellikle kısa vadeli olmasıdır. Bu durumda bankalar kısa vadeli doğabilecek likidite ihtiyaçlarını giderebilmek uğruna varlıklarını satabilme ihtimali ile hatta değerinden daha düşük bir bedel ile satılması riski ile karşı karşıya kalacaklardır (OECD, 2010).

Sorunlu kredilere neden olabilecek bir diğer faktör ise gelişmekte olan ülkelerde finansal piyasaların etkin bir şekilde işlememesi sonucunda kişilerin yükümlülüklerini ödeyememeleri olduğu söylenebilir. Çünkü bankacılık sektöründe sorunlu kredilerin kapsamı, bankacılık ya da finansal krizlerin ortaya çıkmasında önemli bir etmendir (Greenidge \& Grosvenor, 2010).

Genel anlamda sorunlu kredilere neden olabilecek etmenleri; ülke ekonomisinin temel yapı taşlarında bozulma ya da kötüye gitmesi, bankalarda kredi risk ölçüm yönetimin etkin olmaması ve kredi kullanımının bilinçsiz yapılması gibi sıralamak mümkündür (Mileris, 2014).

Özellikle Türk bankacılık sisteminde sorunlu krediler 2001 yılında yaşanan finansal kriz ile kayda değer artış göstermiştir. Özellikle 2001 krizi ile birlikte verilen kredilerin hemen hemen $\% 50$ 'sinden fazlası sorunlu kredi ya da batık kredi haline dönüşmüştür. 
Grafik 1: Türkiye'de Ticari Tüm Bankaların Toplam Krediler İçerisinde Sorunlu Kredilerin Payının Yıllar İtibarıyla Gelişmişi (2005- 2017)(\%)

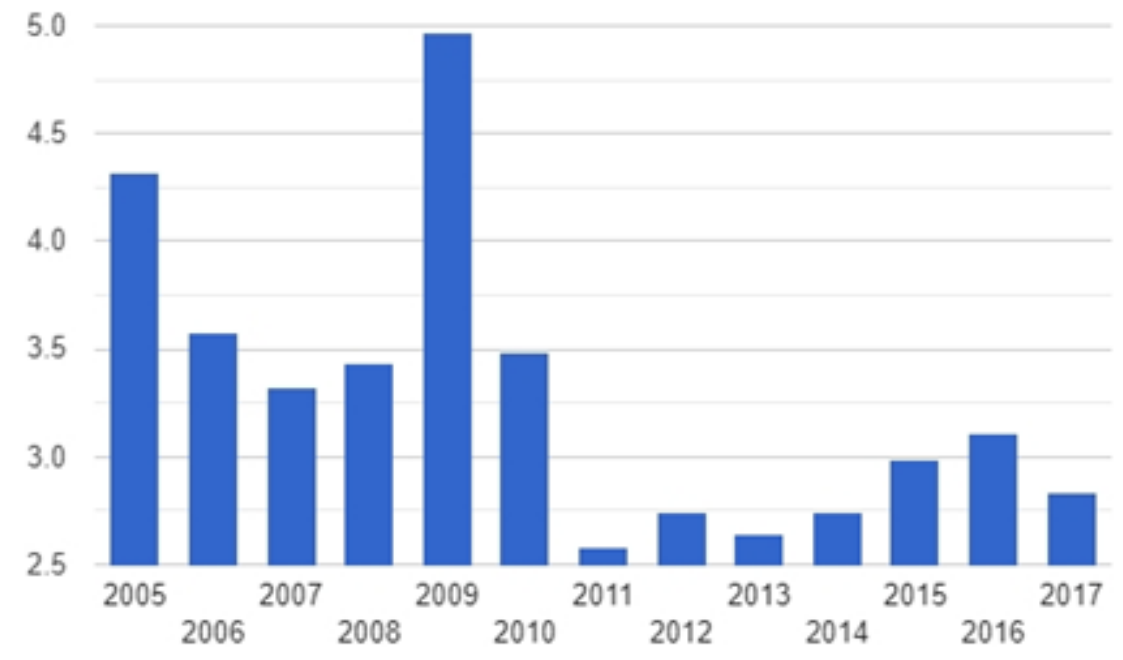

Kaynak: https://www.theglobaleconomy.com/Turkey/Nonperforming_loans/ (31.05.2019)

Bankacılık sektöründe 2005 yılından itibaren 2001 krizi ile birlikte en üst seviyesine ulaşan sorunlu krediler bu yıldan itibaren bankacılık sisteminde yapılan köklü reformlar sayesinde ve bunun sonucunda bankacılık sisteminin daha sağlam bir yapıya kavuşmasıyla 2007 yılına kadar kayda değer ölçüde düşüş trendine girmiştir. Ancak Dünyada tüm ülkeleri etkileyen 2008 küresel finansal kriz sonucunda 2009 yılında sorunlu krediler artış gösterse de 2016 y1lına kadar düşüş trendi devam etmiştir. 2014 y1lından itibaren Türkiye çevresinde yaşanan gelişmeler sonucunda jeopolitik risklerde artış, politik risk ve kurlarda yaşanan artış trendi sorunlu kredilerin artmasına neden olmuştur.

Grafik 2: Türkiye’de Sorunlu(Takipteki) Kredilerin Brüt Gelişimi (Milyar TL) (2010-2019 Mart)

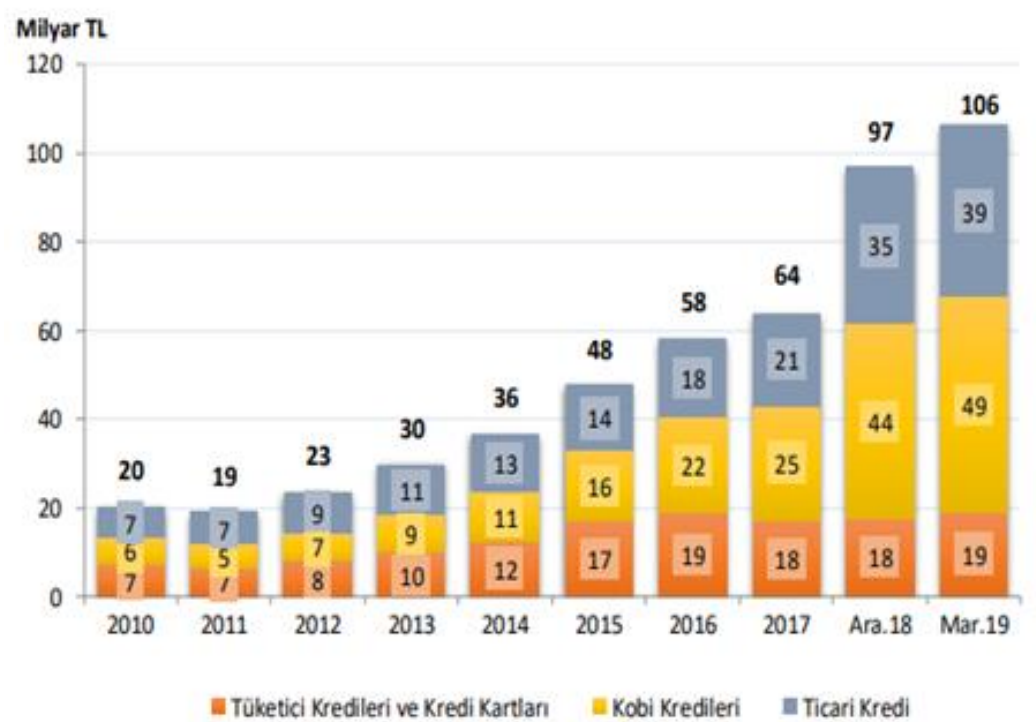

Kaynak:https://www.bddk.org.tr/ContentBddk/dokuman/duyuru_0689_01.pdf (31.05.2019)

Not: Mart 2019 dönemi itibarıyla takipteki kredilerin (brüt) tutarı 106 milyar TL'dir. 
Sorunlu krediler bankacılık sektörü üzerinde kredi bazında incelendiğinde yıllar itibariye takipteki kredilerin brüt gelişiminde daha yüksek pay alan ticari krediler 2015 y1lından itibaren KOBİ kredilerinin takibe dönüşüm oranından daha düşük seviyelerde yer almaya başlamıştır. Özellikle 2018 y1lından itibaren döviz sepetinde yaşanan artış, ülkemiz çevresinde yaşanan jeopolitik risklerin artması ve siyasi risk gibi unsurların ekonomi yapı taşlarında bozulmanın etkisiyle, hükümetin ekonomiyi toparlanması hususunda Kobilere verilen kredilerin geri dönmeyişinden etkili olabileceği söylenebilir.

Grafik 2' e göre 2010-2019 Mart ayı itibariyle Türkiye'de ki sorunlu kredilerin gelişimine bakıldığında üç farklı kredi türünün hemen hemen benzer bir dağılım içinde oldukları fakat 2017 yılından itibaren takipteki kredilerin (brüt) tutarları önemli ölçüde artış göstermiştir. Bu duruma neden olan husus özellikle son zamanlarda Türkiye çevresinde yaşanan jeopolitik riskler ve politik riskten kaynaklanmaktadır. Sorunlu kredilerin hangi sektörler üzerinde etkisini gösterdiğini ortaya koyan Grafik 3 'e baktığımızda sektörel krediler içerisindeki takibe dönüşüm oranları; toptan ticaret ve komisyonculukta $\% 6,63$, inşaat sektöründe $\% 6,11$ ve perakende ticaret ve kişisel ürünler sektöründe \%5,29 olarak gerçekleşmiştir. Bankalar söz konusu takibe dönüşüm oranı ve mali tablolarına yansıtmak suretiyle tahsil edemedikleri portföy değer kayıplarını, vadelerinde ertelemeye gittikleri kredi kullandırışlarını ve kredi portföylerindeki cari kayıpları karşılık ayırmak suretiyle raporlamaktadırlar (Altunöz, 2018).

Grafik 3: Türkiye'de Seçilmiş Sektörlere ilişkin Takibe Dönüşüm Oranları

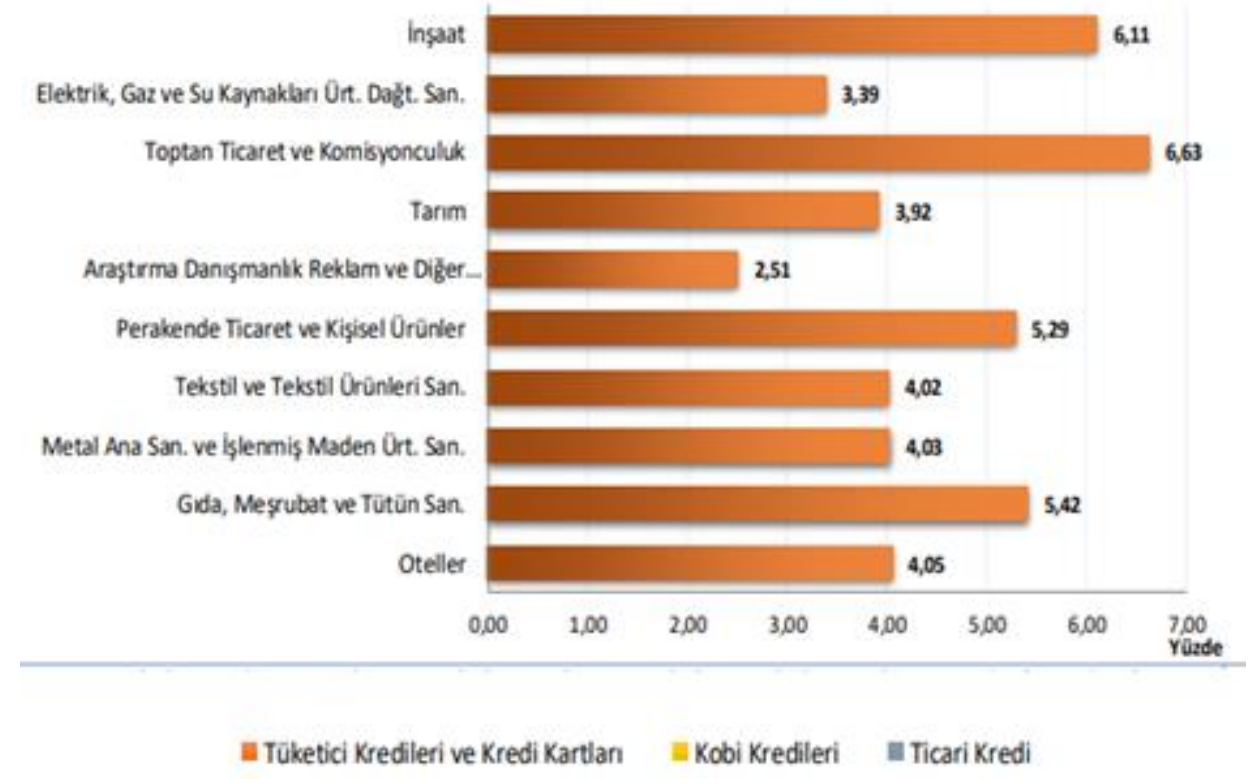

Kaynak:https://www.bddk.org.tr/ContentBddk/dokuman/duyuru_0689_01.pdf (31.05.2019)

Grafik 4: Türk Bankacılık Sektöründe Takibe Dönüşüm Oranı (\%) 


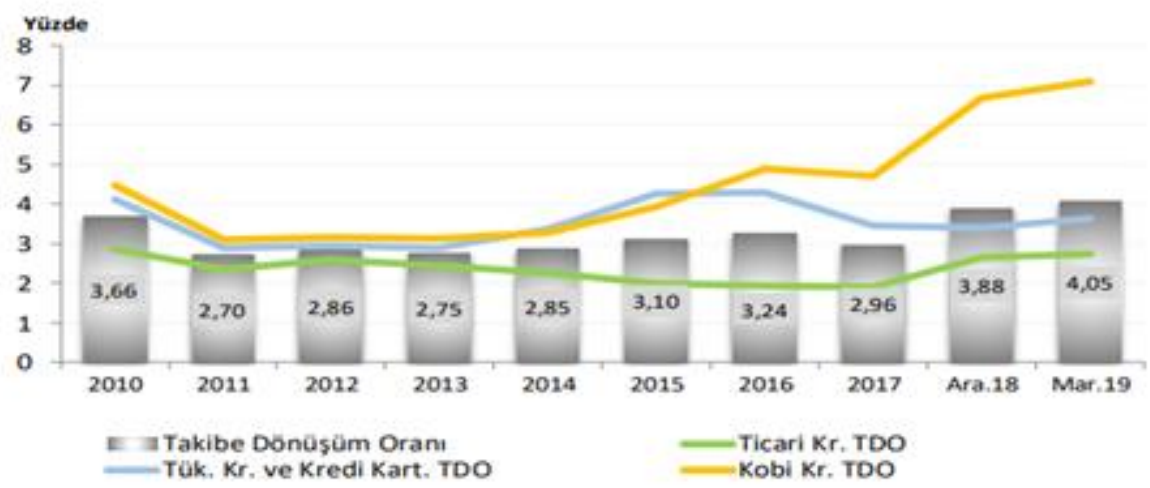

Kaynak:https://www.bddk.org.tr/ContentBddk/dokuman/duyuru_0689_01.pdf (31.05.2019)

Grafik 4 'de ilgili verilere bakıldığında 2008 yılında küresel kriz sonrasında yaşanan olumsuzluklar sonucunda takibe dönüşüm oranında bir artış gözlemlenmesine rağmen 2010 yılında sorunlu alacak bakiyesinde azalma ve kredi hacminin genişlemesi sonucunda oran \%3.66 lara düşmüştür. Bu düşüşte en önemli faktör makroekonomik tedbirlerini alınmasından kaynaklanabileceği söylenebilir. Bu dönüşüm oran1 2017 y1lı sonuna kadar benzer oranda seyrini devam ettirmiştir. 2012, 2015 ve 2016 yıllarında her ne kadar bir artış gözlemlense de bu artış kredilerin yaşlandırılmasın etkili olabileceği düşünülmektedir. 2018 yılına geldiğimizde ve 2019 Mart ayı itibariyle takibe dönüşüm oranında bir artış gözlemlenmiştir. Bu artışın temel nedeni döviz sepetinde yaşanan artış, ülkemiz çevresinde yaşanan jeopolitik risklerin artması ve siyasi risk gibi unsurların ekonomi yapı taşlarında bozulmanın etkili olduğu söylenebilir. Özellik son dönemlerde işletmelerin konkordato ilan etmesi gibi hususlar bankaların sorunlu kredi oranlarında artışını tetiklemiştir.

\section{Literatür}

Bankacılık sektöründe sorunlu kredilerin analizi literatür açısından bankaya özgü ve makroekonomik faktörler açısından ele alınmaktadır. Bankaya özgü olarak bankanın büyüklüğü, kredi dönemleri, maliyet etkinliği vb değişkenler yer alırken, makroekonomik değişkenler olarak GSMH büyüme oranı, enflasyon, reel döviz kuru işsizlik, reel faiz oranlar sorunlu krediler üzerinde anlamlı sonuçlar verebilecek değişkenler olarak ifade edilmektedir.

Fofack (2005), 1995-2009 yılları arasında Afrika'da aşağı sahra ülkelerinde bankacılık sistemlerinde sorunlu krediler ile diğer makroekonomik parametreler arasındaki ilişki ortaya koymak için yaptığ faiz oranları ve reel döviz kuru artışı gibi değişkenler ile sorunlu(takipteki) krediler arasında anlamlı bir ilişkinin olduğu ortaya koyulmuştur.

Mavili (2008), Türkiye'de 2008 yılında 46 şirkete ait bilgiler sonucunda hesaplanan 47 finansal oran arasındaki ilişki istatistiki olarak Logit Regresyon Modeli ortaya koyulmaya çalışılmıştır. Çalışma sonucunda ilgili şirketlerin finansal oranları ile sorunlu krediler ile anlamlı bir ilişkinin varlığ belirtilmiştir.

Podpiera ve Weill (2008) 1994-2005 yılları arasında yaptıkları çalışmada çek ticari bankalarında sorunlu krediler ile bankaya özgü faktörlerden olan maliyet etkinliği arasındaki ilişki dinamik panel tekniği ile ortaya koyulmaya çalışılmıştır. Çalışma sonucunda maliyet etkinliğinin bozulmasının sorunlu krediler üzerinde olumsuz etki yarattığını gözlemlemişlerdir.

Şahbaz (2010), Türkiye'de 1998-2009 y1lları arasında sorunlu krediler üzerinde etkili olabilecek makroekonomik parametreler ile sorunlu krediler arasında anlamlı bir ilişkinin olup olmadığı VAR Analizi ile ortaya koyulmaya çalışılmıştır. Çalışma sonucunda Türkiye'de sorunlu 
kredileri ile GSYİH, özel tüketim harcamaları, yurt içi kredi hacmi ve özel sabit sermaye yatırımları gibi makroekonomik parametreler arasında uzun dönemli bir ilişkinin mevcudiyeti belirtilmiştir.

Boudriga v.d (2009), 2002-2006 yılları arasında 59 ülkeyi dahil ettikleri çalışmada sorunlu krediler ile etkili olabilecek faktörleri belirleyebilmek amacıyla çalışma yapmışlardır. Çalışma sonucunda sermaye yeterlilik oranı, kredi karşılık oranlarının sorunlu krediler üzerinde etkili oldukları, bunun yanında piyasa düzenleme, denetleme ve piyasa disiplinin sorunlu krediler üzerinde etkili olmasına rağmen tek başlarına yeterli olmadığını ifade edilmiştir.

Adela ve Julia (2010), 2006-2010 yılları arasında Romen bankacılık sistemini ele aldıkları çalışmada sorunlu krediler ile bankaya özgü faktörlerden olan ortalama faiz oranı arasında ilişki ortaya koymaya çalışmışlardır. Çalışma sonucunda sorunlu kredileri etkileyebilecek dolaylı parametrelerinde olduğunu ve kredi teminatlarının fiyatlarının düşmesi enflasyon baskısı nedenlerinden dolayı aradaki ilişkinin negatif yönde olduğunu belirtilmiştir.

Nkusu, (2011), gelişmiş ülkeler üzerinde 1998-2009 yılları arasında çeşitli makro ekonomik parametreler ile sorunlu krediler arasındaki ilişki Panel Regresyon Analizi ortaya konmaya çalışılmıştır. Çalışma sonucunda işsizlik oranı, kredi fiyatları ve büyüme oranları gibi makro ekonomik değişkenlerde yaşanabilecek bozulmalar sorunlu kredileri arttırdığı gözlemlenmiştir.

Beck v.d.(2013), 2013 yılında 75 ülkeyi ele alan çalışmalarında sorunlu kredilere neden olan makroekonomik değişkenleri belirlemeye çalışmışlardır. Çalışma sonucunda sorunlu krediler üzerinde etkili olabilecek makroekonomik parametrelerin reel döviz kuru, GSMH büyümesi (reel), hisse senetleri, borç verme faizi olarak gözlemlemişlerdir. Bunun yanında gelişmiş hisse senedi piyasalarında hisse senetleri fiyatlarının, GSMH'ye nazaran daha etkili olduğu ortaya koymuşlardır.

Klein (2013), Orta, Doğu ve Güneydoğu Avrupa'da 1998-2011 yılları arasında sorunlu krediler üzerinde etkili olabilecek makroekonomik parametreler ile sorunlu krediler arasında anlamlı bir ilişkinin olup olmadığı Panel Veri Analizi ile belirlenmeye çalışılmıştır. Çalışma sonucunda enflasyon, işsizlik, GSYİH gibi makroekonomik parametrelerin sorunlu krediler üzerinde anlamlı bir etkisinin olduğu gözlemlenmiştir.

Roy (2014), 1995-2012 yılları arasında Hindistan bankaları üzerinde sorunlu kredilerin nedenlerini ortaya koymak için yaptığı çalışmada panel veri analizi istatistiki tekniğinden yararlanılmıştır. Çalışma sonucunda VIX endeksi, GSMH' daki büyüme, döviz kurundaki değişimlerin sorunlu krediler üzerinde etkili olduğu ifade edilmiştir.

Altunöz (2018), 2005-2016 yılları arasında faaliyetlerine kesintisiz devam eden 25 Türk Ticari Bankanın kredi kayıp karşılığı ile bankaya özgü ve makro ekonomik değişkenlerin etkileşimi zaman serileri ve panel veri analizleri ile ortaya koyulmaya çalışılmıştır. Çalışma sonucunda ekonomik büyüme, kur ve M3 para arzının kredi kayıp karşılığı ile etkileşimde olduğu buna karşın enflasyon, faiz, aktif büyüklüğü ve personel sayısı istatistiki olarak anlamlı sonuçlar vermemiştir.

Torun ve Altay (2019), 2008-2015 yılları arasında faaliyetlerine kesintisiz devam eden 25 Türk Ticari Bankanın sorunlu kredilerine sebep olan bankaya özgü ve makro ekonomik değișkenler dengeli statik panel veri analizi ile ortaya koyulmaya çalışılmıştır. Çalışma sonucunda sorunlu krediler üzerinde etkili olan makro ekonomik faktörlerin enflasyon, GSMH, BIST 100 endeksi, reel faiz oran1, tüketici kredi payı, sermaye yeterlilik rasyosu, banka büyüklüğü ve mevduatın krediye dönüşüm oranının etkili olduğu sonucuna ulaşmışlardır. 


\section{Veri Ve Metodoloji}

\subsection{Veri}

Çalışmada Türkiye'de 2005-2018 yılları arasında bankacıllk sektöründe faaliyet gösteren 25 adet ticari bankanın sorunlu kredileri ele alınmıștır. Sorunlu krediler ile makroekonomik parametrelerin etkileşimi panel veri analizi ile test edilecektir. Parametreler belirlenirken genel literatür incelenmiş ve sorunlu krediler ile anlamlı olduğu düşünülen değişkenler kullanılmıştır. Bankaya özgü ile makroekonomik parametrelere ilişkin veriler Bankacılık Denetleme ve Düzenleme Kurumu (BBDK), Türkiye Bankalar Birliği (TBB), Türkiye Cumhuriyeti Merkez Bankası (TCMB) ve Türkiye İstatistik Kurumu (TÜIK) tarafından temin edilmiştir.

Tablo 1: Araştırma Kapsamında Yer alan Bankalar

\begin{tabular}{llll}
1 & Akbank & 14 & ING Bank \\
2 & Alternatifbank & 15 & Şekerbank \\
3 & Anadolubank & 16 & The Royal Bank of Scotland \\
4 & Arap Türk Bankası & 17 & Turkish Bank \\
5 & Bank Mellat & 18 & Turkland Bank \\
6 & Burgan Bank & 19 & Türk Ekonomi Bankası \\
& & & Türkiye Cumhuriyeti Ziraat \\
7 & Citybank & 20 & Bankası \\
8 & Denizbank & 21 & Türkiye Garanti Bankası \\
9 & Fiba Bank & 22 & Türkiye Halk Bankası \\
10 & Finans Bank & 23 & Türkiye İş Bankası \\
11 & Habipbank & 24 & Türkiye Vakıflar Bankası \\
12 & HSBC Bank & 25 & Yapı ve Kredi Bankası \\
13 & ICBC Turkey Bank & & \\
\hline
\end{tabular}

Kaynak: www.tbb.org.tr

Tablo 2: Çalışmada Kullanılan Değişkenler

\begin{tabular}{|l|l|l|l|}
\hline Sembol & Bankaya Özgü Faktörler & Sembol & Makro Ekonomik Değişkenler \\
\hline B1 & Reel Efektif Faiz Oranı, & M1 & Gayri Safi Yurt İçi Hasıla (GSYİH), \\
\hline B2 & Aktif Kârlıı̆̆ı, & M2 & Reel Döviz Kuru (RDK), \\
\hline B3 & Aktif Büyüklüğ̈, & M3 & Ticari Kredi Faiz Oranı (FO) \\
\hline B4 & Türk Paras1 Kredilerinin Pay1, & M4 & Borsa İstanbul-100 (BİST) endeksi \\
\hline B5 & Mevduatın Krediye Dönüşüm Oran1, & M5 & Bankalar Arası Gecelik Ortalama Faiz Oranı \\
\hline B6 & Sermaye Yeterlilik Rasyosu & M6 & Enflasyon= Tüfe Değişim Hızı \\
\hline B7 & Öz sermaye Kârlılı̆̆1, & M7 & Parasal Büyüklük= Parasal Taban/ TUFE \\
\hline B8 & Kredi Büyüme Oranı, & M8 & İşsizlik Oranı, \\
\hline B9 & Tüketici Kredilerinin Payı & & \\
\hline
\end{tabular}

Burada sorunlu kredilerin üç ana bacağını ortaya koyabilmek amacıyla, pazar payı açısından GSYIH, maliyet açısından FO ve işletmelerin durumunu ortaya koyabilmek BİST-100 kullanılmıştır. Burada sorunlu kredilerin tek başına bağımlı değişken olarak seçilmesinin ana nedeni, sorunlu kredilerin bankaların finansal performansını ortaya koymak için önemli bir gösterge teşkil etmesi ve kredi kullanan tüzel kurumların kredi ödeyebilme yeteneğini etkileyen parametrelerin belirlenerek gelecekte alınacak kararlara öncülük edilmesidir. Bunun yanında sorunlu krediler aynı zamanda kredi riskini ortaya koymakta ve temerrütte düşme olasılığını arttırıcı bir unsurt olarak değerlendirilmektedir. Çalışma kullanılan yöntem ve mevcut dönem açısından diğer çalışmalardan 
farklılık arz etmekte ve ilgililere katkı sağlayacağ düşünülmektedir. Çalışmada sorunlu kredilerin göstergesi olarak

$$
\mathrm{SK}=\frac{\text { Takipteki alacaklar }}{\text { Toplam krediler }}
$$

Modelde sorunlu krediler oranı üzerinde etkileşim derecesi olduğu düşünülen hem bankaya özgü hem de makro ekonomik parametreler analize dahil edilmiş olup, ilgili model Havuzlanmış Regresyon Modeli çerçevesinde analiz edilmiştir: Bu amaçla kurulan model denklemi (1) aşağıda yer almaktadır.

$$
S K_{i t}=
$$

$\beta_{1} B_{1 t}+\beta_{2} B_{2 t}+\beta_{3} B_{3 t}+\beta_{4} B_{4 t}+\beta_{5} B_{5 t}+\beta_{6} B_{6 t}+\beta_{7} B_{7 t}+\beta_{8} B_{8 t}+\beta_{9} B_{9 t}+\beta_{10} M_{1 t}+\beta_{11} M_{2 t}+\beta_{12} M_{3 t^{+}}+$

$\beta_{13} M_{4 t}+\beta_{14} M_{5 t}+\beta_{15} M_{6 t}+\beta_{16} M_{7 t}+\beta_{17} M_{8 t}+\varepsilon i, t$

Eşitlik (1) de $S K_{i t}$ sorunlu kredileri ifade ederken diğer B ile ifade eden değişkenler $\mathrm{t}$ zamanında bankaya özgü değişkenler, $\mathrm{M}$ ile ifade edilen değişkenler t zamanında makro ekonomik değişkenleri ve $\varepsilon i, t$ hata düzeltme katsayısını ifade etmektedir.

\subsection{Metodoloji}

Bankacılık sektöründe faaliyet gösteren ticari bankaların sorunlu kredilerinin belirlenmesi hususunda panel ve zaman serisi analizleri yöntemleri kullanılmakta ve bunlardan panel veri analizi kullanımı en kapsamlı ve sağlıklı sonuçlar veren bir analiz yöntemi olarak karşımıza çıkmaktadır. Panel veri yöntemi kullanılmasının nedeni ilgili parametrelerin sadece bankacılık sektörü üzerinde değil banka bazında inceleme yapmasından kaynaklanmaktadır.

Günümüzde panel veri analizinin en aktif ve en yenilikçi hale gelmesinin nedenlerinin başında özellikle tahmin yöntemleri ve teorik altyapısının gelişiminden kaynaklanmaktadır (Greene, 2003).Bunun yanında panel veri analizinin iki boyutlu bir analiz türü olması bünyesinde birçok avantaji bulundurmaktadır. Bu sayede yapısında hem yatay hem de zaman kesit verilerini bir araya getirmesinden dolayı, daha fazla veriyle daha yüksek serbestlik derecesi ile tahmin yapmayı sağlamaktadır. Bu sayede gözlem sayısı arttığı zaman çoklu doğrusal bağlantı sorunu elemine edilmektedir (Hsiao, 2002). Bunun yanında panel veri analizi yatay kesitlere özgü heterojenliği göz önüne alması, kapsamlı modelleri test edebilmesi, model belirleme sorunu nedeniyle ortaya çıkan kusurlara çözüm getiren yöntemleri bünyesinde bulundurması ve çoklu doğrusal bağlantıları azaltması panel veri analizi yönteminin sağladığı avantajlar arasında öne çıkan kısımlarıdır (Greene W. , 2012).

Panel veri analizi modelleri, yatay kesit bağımlılığ barındırmadı̆̆ varsayımı, birimler arasında ve birim içinde homoskedastik (sabit varyansl1) olduğu ve birim içinde otokorelasyon olmadığı varsayımlarına dayanmaktadır. Bu varsayımların gerçekleşmesi koşuluyla panel veri analizine uygun tahmin yöntemlerinden biri seçilebilecektir (BALTAGİ, 2013).

Panel veri analizi sabit, eğim ve hata terime ilişkin varsayımlara bağlı olarak farklı şekillerde modellenebilmektedir. Panel veri analizi, Havuzlanmış En Küęük Kareler (HEKK - Pooled OLS, Klasik Model), Sabit Etkiler (Fixed Effects) ve Rassal Etkiler (Random Effects) yaklaşımlarından biri kullanılarak tahmin edilmektedir (Wooldridge, 2009). Birim ve zaman etkilerinin homojen olduğu durumda, hata terimi her iki etkiyi de içermediği durumda, etkin ve tutarlı tahminciler veren HEKK Yöntemi, eğim parametrelerinin tüm yatay kesit birimler için aynı, sabit parametrenin birimler arasında farklılaştığı (birim etki içerdiği) durumda Sabit Etkiler (SE) yaklaşımı ve eğim parametreleri yatay kesitler arasında değişiyorsa ve örnekteki birimler rassal olarak seçildiği durumda ise Rassal Etkiler (RE) yaklaşımı kullanılmaktadır (Önder, 2017). Çalışma sorunlu krediler ile diğer değişkenler arasındaki ilişkinin stabil olduğu varsayımıyla en uygun yöntemin Havuzlanmış En Küçük Kareler (HEKK - Pooled OLS, Klasik Model) yöntemi tercih edilmiştir. 
Çalışmada panel veri analizinden yararlanılmış olup, bu analiz türü hem zaman serisi hem de yatay kesit verilerinin birlikte kullanımına olanak sağlamaktadır. Bundan dolayı panel veri analizinde veri setleri hem zaman serisi hem de yatay kesit boyutuna sahip oldukları için her iki yöntemin ayrı ayrı kullanımında ya da her iki yöntemin tek başlarına kullanılmadığı modellerin daha kolay ve sağlıklı bir şekilde analizine olanak sağlamaktadır.

Rassal Etkiler Modelinde (Random Effects) birimlere ve zamana göre ya da sadece birimlere göre meydana gelen değişiklikler modele bir hata terimi bileşeni olarak dahil edilmektedir. $\mathrm{Bu}$ çalışmada ilgili veri seti dikkate alınarak tüm ticari bankaların modele dahil edilmediği ve Havuzlanmış En Küçük Kareler (HEKK - Pooled OLS, Klasik Model) yöntemi tercih edilmiştir.

Panel veri analizi yönteminde yatay kesit ve zaman serilerinin birlikte kullanımı çeşitli problemleri beraberinde getirmektedir. Bundan dolayı yatay kesit bağımlılığı (hata teriminin birimler arasında korelasyon) ve zaman serilerinde karşılaşılan birim kök varlığ problemleri göz önünde bulundurulmalıdır (Bilman, 2014). Yatay kesit bağımlılığı için zaman serilerinde karşılaşılan birim kök varlığı problemi için Im, Peseran, Shin (2003) birim kök testi kullanılacaktır.

Panel veri analizi çalmalarında birim kök testleri; bireysel birim kök testleri Im, Peseran, Shin (2003)(IPS) ile Levin, Lin, Chu (2002) (LLC) ortak birim kök testleri ile sınanmaktadır. Bu çalışmada her iki testten faydalanılmıştır. ifade edilebilir.

Im, Peseran, Shin (2003) testini hem sabit hem de trendli olarak aşağıda yer alan denklemle

$$
\Delta y_{i t}=\mu_{i}+\beta_{i} y_{i, t-1}+\sum_{k=1}^{p_{i}} \theta_{i, k} \Delta y_{i, t-k}+\gamma_{i} t+\varepsilon_{i t}
$$

İlgili testte $H_{O}$ hipotezi bütün yatay kesit birimleri (i) için $\beta_{i}=0$ şeklinde, $H_{1}$ hipotezi gerekli kritik değerler ise en az bir yatay kesit birimi $\left(\beta_{i}<0\right)$ şeklinde oluşturulur. Eğer $H_{O}$ hipotezi reddedilirse serilerinden en birinin durağan olduğu sonucuna ulaşı1ır ve bu test için ilgili kritik değerler Im, Peseran, Shin (2003) tablosundan alınmaktadır. İlgili denklemden trend çıkarıldığı zaman ise sabit modele ulaşılmaktadır.

Levin, Lin, Chu (2002) (LLC) ise ortak bir birim kök oluşturulması gerektiğini, bireysel birim kök testlerinin ise alternatif hipotezlere karşı etkisinin zayıf kaldığını ifade etmektedir. Bir başka ifadeyle Levin, Lin, Chu (2002) (LLC) her bir yatay kesit birimi için bireysel birim kök testlerine nazaran daha güçlü ve daha sağlıklı sonuçlar veren ortak bir panel birim kök testi önermektedir. Levin, Lin, Chu (2002) birim kök testi istatistiklerindeki regresyon tanımlamalarının altında asimptotik varyans ve ortalamalarının değiştiğini gözlemlemişlerdir (Levin, 2002). Levin, Lin, Chu aşağıda yer alan denklemle ifade edilebilir (BALTAGI, 2005).

$$
\Delta y_{i t}=\rho_{i} y_{i, t-1}+\sum_{L=1}^{p_{i}} \theta_{i, L} \Delta y_{i, t-L+} \alpha_{m i} d_{m t}+\varepsilon_{i t} \quad m=1,2,3
$$

İlgili denklemde $d_{m t}$ deterministik değişkenler vektörünü, $\alpha_{m i}$ ise modelin katsayılar vektörünü ifade etmektedir. $\rho_{i}$ gecikme uzunluğunu, $\rho_{\max }$ maksimum lag uzunluğunu, $\alpha_{m}$ parametreleri ve $\varepsilon_{i t} \quad$ hata terimini ifade etmektedir. Levin, Lin, Chu (2002) ilgili modelde testlerini gerçekleştirmek için üç farklı model öngörmektedir. Bu modeller sabit parametresiz, sabit parametreli ve sabit parametreli ve trendli olmak üzere üç farklı modelle oluşturulmaktadır.

$$
\begin{aligned}
& \text { Sabitli Model }=\Delta y_{i t}=\rho_{i} y_{i, t-1}+u_{i t} \\
& \text { Sabitli-Trendli Model }=\Delta y_{i t}=\alpha_{o i}+\rho_{i} y_{i, t-1}+u_{i t} \\
& \text { Sabitsiz-Trendsiz Model }=\Delta y_{i t}=\alpha_{o i}+\alpha_{1 i t}+\rho_{i} y_{i, t-1}+u_{i t}
\end{aligned}
$$

Burada $u_{i t}$ hata sürecini ifade etmektedir. Sabitli modelde $H_{O}=p=0$ durumunu $H_{1}: p<0$ durumunu incelemektedir. Sabitli-Trendli model ise $y_{i t}$ serilerinin zaman trendi içermeyen bireysel bir 
ortalamaya sahip olduğunu yani tüm $i$ durumlarında $H_{O}=p=0 \quad \alpha_{o i}=0$ ile $H_{1}: p<0 \quad \in R$ olarak kabul edilmektedir. Sabitsiz-Trendsiz modelde ise $y_{i t}$ serilerinin hem zaman trendi hem de bireysel bir ortalamaya sahip olduğunu yani tüm $i$ durumlarında $H_{O}=p=0 \quad \alpha_{1 i}=0$ ile $H_{1}: p<0 \quad \alpha_{1 i} \in R$ olarak kabul edilmektedir.

Panel veri tahmininde iki farklı yöntem kullanılmaktadır. Bunlar sabit etkiler ve rassal etkiler modelleridir. Sabit etkiler modeli, birimler arasında bireysel farklılıkların, sabit terimde yer alan farklılıklarla ortaya çıkarılabileceğini varsaymaktadır. Bu sayede her bir değișken, zaman göre değişmeyen bir sabit terime yani model dışında bırakılan bağımsız değişkenlerin etkilerini gösterecektir. Rassal etkiler modeli ise sabit etkiler modelin tüm varsayımlarının yanında bireysel ve zaman etkilerinin bağımsız değişkenler ile ilişkili olmadığını kabul etmektedir.

Panel veri regresyon modellerinin temel varsayımlarından biri değişkenlerin durağan bir yapı sergilemesidir. Sahte regresyon sorunun ortadan kaldırılıp her bir değişkenin durağan düzeyleri ile regresyon analizine dahil edilmesi gerekmektedir. Bu çalışmada serilerin durağanlığı Levin Lin ve Chu (LLC) ve Im, Pesaran ve Shin (IPS) birim kök testleri kullanılarak sabitli, sabitli-trendli ve none(sabitsiz-trendsiz) modelleri çerçevesinde $\% 5$ anlamlılık düzeyinde analiz edilmiştir. Im, Pesaran ve Shin (IPS) birim analizde sabitli ve sabitli-trendli olmak üzere iki farklı model analiz edilmiştir. Levin Lin ve Chu (LLC) modelinde ise sabitli, sabitli-trendli ve none(sabitsiz-trendsiz) modelleri olmak üzere üç farklı model analiz edilmiştir. Amprik bulgularda aktif karlılığg ve öz sermaye karlılığı değişkenleri haricinde her iki modelde $H_{O}$ hipotezi reddedilmekte ve serilerin durağan olduğu anlaşılmaktadır. 
Tablo 3: Im, Peseran, Shin Birim Kök Test Sonuçları

\begin{tabular}{|c|c|c|c|}
\hline \multirow[b]{2}{*}{ Değişkenler } & \multicolumn{3}{|c|}{ W Test İstatistiği } \\
\hline & Sabit Model & $\begin{array}{l}\text { Sabit- } \\
\text { Trendli } \\
\text { Model }\end{array}$ & Sonuç \\
\hline B1 & $\begin{array}{l}-7.5075 \\
(0.0088)\end{array}$ & \begin{tabular}{|l|}
-3.8012 \\
$(0.0123)$
\end{tabular} & $\begin{array}{l}\mathrm{I}(\mathrm{O})^{*} \\
\mathrm{I}(\mathrm{O})^{* *}\end{array}$ \\
\hline B2 & $\begin{array}{l}-7.5653 \\
(0.6000)\end{array}$ & \begin{tabular}{|l}
-5.9032 \\
$(0.7028)$
\end{tabular} & $\begin{array}{l}\mathrm{I}(\mathrm{O})^{*} \\
\mathrm{I}(\mathrm{O})^{* *}\end{array}$ \\
\hline B3 & $\begin{array}{l}-8.4856 \\
(0.0005)\end{array}$ & \begin{tabular}{|l|}
-8.8465 \\
$(0.0145)$
\end{tabular} & $\begin{array}{l}\mathrm{I}(\mathrm{O})^{*} \\
\mathrm{I}(\mathrm{O})^{* *}\end{array}$ \\
\hline B4 & $\begin{array}{l}-5.9675 \\
(0.2888)\end{array}$ & \begin{tabular}{|l|}
-5.3456 \\
$(0.4113)$ \\
\end{tabular} & $\begin{array}{l}\mathrm{I}(\mathrm{O})^{*} \\
\mathrm{I}(\mathrm{O})^{* *}\end{array}$ \\
\hline B5 & $\begin{array}{l}-6.5785 \\
(0.0502)\end{array}$ & \begin{tabular}{|l|}
-3.2659 \\
$(0.0234)$
\end{tabular} & $\begin{array}{l}\mathrm{I}(\mathrm{O})^{*} \\
\mathrm{I}(\mathrm{O})^{* *}\end{array}$ \\
\hline B6 & $\begin{array}{l}-6.1275 \\
(0.0000)\end{array}$ & \begin{tabular}{|l|}
-5.8765 \\
$(0.0173)$
\end{tabular} & $\begin{array}{l}\mathrm{I}(\mathrm{O})^{*} \\
\mathrm{I}(\mathrm{O})^{* *}\end{array}$ \\
\hline B7 & $\begin{array}{l}-1.2387 \\
(0.6245) \\
\end{array}$ & \begin{tabular}{|l|}
-2.5612 \\
$(0.5489)$ \\
\end{tabular} & $\begin{array}{l}\mathrm{I}(\mathrm{O})^{*} \\
\mathrm{I}(\mathrm{O})^{* *}\end{array}$ \\
\hline B8 & $\begin{array}{l}-2.9565 \\
(0.0328) \\
\end{array}$ & \begin{tabular}{|l|}
-2.8515 \\
$(0.1823)$ \\
\end{tabular} & $\begin{array}{l}\mathrm{I}(\mathrm{O})^{*} \\
\mathrm{I}(\mathrm{O})^{* *}\end{array}$ \\
\hline B9 & $\begin{array}{l}-2.3670 \\
(0.0688)\end{array}$ & \begin{tabular}{|l|}
-2.2412 \\
$(0.2123)$
\end{tabular} & $\begin{array}{l}\mathrm{I}(\mathrm{O})^{*} \\
\mathrm{I}(\mathrm{O})^{* *}\end{array}$ \\
\hline M1 & $\begin{array}{l}-8.3443 \\
(0.0000)\end{array}$ & \begin{tabular}{|l}
-5.1232 \\
$(0.0018)$
\end{tabular} & $\begin{array}{l}\mathrm{I}(\mathrm{O})^{*} \\
\mathrm{I}(\mathrm{O})^{* *}\end{array}$ \\
\hline M2 & $\begin{array}{l}-7.2354 \\
(0.1288)\end{array}$ & \begin{tabular}{|l|}
-7.3476 \\
$(0.1013)$
\end{tabular} & $\begin{array}{l}\mathrm{I}(\mathrm{O})^{*} \\
\mathrm{I}(\mathrm{O})^{* *}\end{array}$ \\
\hline M3 & $\begin{array}{l}-8.5075 \\
(0.0127) \\
\end{array}$ & $\begin{array}{l}-5.1543 \\
(0.0120) \\
\end{array}$ & $\begin{array}{l}\mathrm{I}(\mathrm{O})^{*} \\
\mathrm{I}(\mathrm{O})^{* *}\end{array}$ \\
\hline M4 & \begin{tabular}{|l}
-1.8775 \\
$(0.3288)$ \\
\end{tabular} & \begin{tabular}{|l|}
-1.4612 \\
$(0.6320)$ \\
\end{tabular} & $\begin{array}{l}\mathrm{I}(\mathrm{O})^{*} \\
\mathrm{I}(\mathrm{O})^{* *}\end{array}$ \\
\hline M5 & $\begin{array}{l}-2.1675 \\
(0.2188)\end{array}$ & \begin{tabular}{|l|}
-2.7412 \\
$(0.2223)$ \\
\end{tabular} & $\begin{array}{l}\mathrm{I}(\mathrm{O})^{*} \\
\mathrm{I}(\mathrm{O})^{* *}\end{array}$ \\
\hline M6 & $\begin{array}{l}-6.1275 \\
(0.0000)\end{array}$ & \begin{tabular}{|l}
-3.8562 \\
$(0.0112)$
\end{tabular} & $\begin{array}{l}\mathrm{I}(\mathrm{O})^{*} \\
\mathrm{I}(\mathrm{O})^{* *}\end{array}$ \\
\hline M7 & $\begin{array}{l}-3.4523 \\
(0.0004)\end{array}$ & \begin{tabular}{|l|}
-3.4508 \\
$(0.0176)$
\end{tabular} & $\begin{array}{l}\mathrm{I}(\mathrm{O})^{*} \\
\mathrm{I}(\mathrm{O})^{* *}\end{array}$ \\
\hline M8 & $\begin{array}{l}-3.4576 \\
(0.0129)\end{array}$ & \begin{tabular}{|l}
-3.4654 \\
$(0.2112)$
\end{tabular} & $\begin{array}{l}\mathrm{I}(\mathrm{O})^{*} \\
\mathrm{I}(\mathrm{O})^{* *}\end{array}$ \\
\hline
\end{tabular}

Not: $\% 5$ anlamlılık düzeyinde sabit ve sabit-trend'li kritik değer sırasıyla-2.1452 ve -3.1243'dür.( ) değerleri Olasılık (p) değerini vermektedir.*Sabit model durağanlığını, **Sabit-Trendli model durağanlığını ifade etmektedir.

Durağanlık analizinde yukarıda ifade edildiği üzere ilgili serilerde kullanılan bir diğer test ise Levin, Lin, Chu (2002) birim kök testidir. Tablo xxx yer alan test sonuçlarından görüleceği üzere testlerde sabitli, sabitli-trendli ve sabitsiz-trendsiz(none) olmak üzere üç model dikkate alınmıştır. Amprik sonuçlar incelendiğinde her üç modelde ilgili tüm değişkenler için \%1 anlamlılık seviyesinde $H_{O}$ reddedildiği yani bütün serilerin durağan olduğunu göstermektedir. Değişkenlerin gecikme değerleri Schwartz Bilgi Kriteri (SIC)'ne göre otomatik olarak belirlenmiştir. Her iki durağanlık testlerinden de görüleceği üzere ilgili modelde yer alan tüm değişkenlerin düzeyde durağan oldukları$\mathrm{I}(0)$ anlaşılmaktadır. 
Tablo 4: Levin, Lin, Chu Birim Kök Test Sonuçları

\begin{tabular}{|c|c|c|c|}
\hline Değişkenler & Model & $\mathrm{t} *$ istatistiği & Sonuç \\
\hline \multirow{3}{*}{$\begin{array}{l}\text { Reel Efektif Faiz } \\
\text { Oran1, }\end{array}$} & Sabitli & $-7,243^{*}$ & $\mathrm{I}(0)$ \\
\hline & Sabitli-Trendli & $-4,127 *$ & $\mathrm{I}(0)$ \\
\hline & None & $-3,102 *$ & $\mathrm{I}(0)$ \\
\hline \multirow{3}{*}{ Aktif Kârlılığg, } & Sabitli & $-9.687 *$ & $\mathrm{I}(0)$ \\
\hline & Sabitli-Trendli & $-8.932 *$ & $\mathrm{I}(0)$ \\
\hline & None & $-6.643^{*}$ & $\mathrm{I}(0)$ \\
\hline \multirow{3}{*}{ Aktif Büyüklüğü, } & Sabitli & $-4,275^{*}$ & $\mathrm{I}(0)$ \\
\hline & Sabitli-Trendli & $-3,264^{*}$ & $\mathrm{I}(0)$ \\
\hline & None & $-14,127 *$ & $\mathrm{I}(0)$ \\
\hline \multirow{3}{*}{$\begin{array}{l}\text { Türk Parası } \\
\text { Kredilerinin Payı, }\end{array}$} & Sabitli & $-13,173 *$ & $\mathrm{I}(0)$ \\
\hline & Sabitli-Trendli & $-12,174 *$ & $\mathrm{I}(0)$ \\
\hline & None & $-20,297 *$ & $\mathrm{I}(0)$ \\
\hline \multirow{3}{*}{$\begin{array}{l}\text { Mevduatın Krediye } \\
\text { Dönüşüm Oranı, }\end{array}$} & Sabitli & $-11,123^{*}$ & $\mathrm{I}(0)$ \\
\hline & Sabitli-Trendli & $-9,675^{*}$ & $\mathrm{I}(0)$ \\
\hline & None & $-17,345^{*}$ & $\mathrm{I}(0)$ \\
\hline \multirow{3}{*}{$\begin{array}{l}\text { Sermaye Yeterlilik } \\
\text { Rasyosu }\end{array}$} & Sabitli & $-10,133^{*}$ & $\mathrm{I}(0)$ \\
\hline & Sabitli-Trendli & $-7,643^{*}$ & $\mathrm{I}(0)$ \\
\hline & None & $-14,109 *$ & $\mathrm{I}(0)$ \\
\hline \multirow{3}{*}{ Özsermaye Kârlılığı, } & Sabitli & $-9,132 *$ & $\mathrm{I}(0)$ \\
\hline & Sabitli-Trendli & $-8,654 *$ & $\mathrm{I}(0)$ \\
\hline & None & $-5,126^{*}$ & $\mathrm{I}(0)$ \\
\hline \multirow{3}{*}{ Kredi Büyüme Oranı, } & Sabitli & $-4,102 *$ & $\mathrm{I}(0)$ \\
\hline & Sabitli-Trendli & $-3,655^{*}$ & $\mathrm{I}(0)$ \\
\hline & None & $-13,437 *$ & $\mathrm{I}(0)$ \\
\hline \multirow{3}{*}{$\begin{array}{l}\text { Tüketici Kredilerinin } \\
\text { Payı }\end{array}$} & Sabitli & $-13,105^{*}$ & $\mathrm{I}(0)$ \\
\hline & Sabitli-Trendli & $-12,652 *$ & $\mathrm{I}(0)$ \\
\hline & None & $-17,127 *$ & $\mathrm{I}(0)$ \\
\hline \multirow{3}{*}{$\begin{array}{l}\text { Gayri Safi Yurt İçi } \\
\text { Hasıla (GSYİH), }\end{array}$} & Sabitli & $-9,631 *$ & $\mathrm{I}(0)$ \\
\hline & Sabitli-Trendli & $-11,138 *$ & $\mathrm{I}(0)$ \\
\hline & None & $-15,787 *$ & $\mathrm{I}(0)$ \\
\hline \multirow{3}{*}{$\begin{array}{l}\text { Reel Döviz Kuru } \\
\text { (RDK), }\end{array}$} & Sabitli & $-8,354^{*}$ & $\mathrm{I}(0)$ \\
\hline & Sabitli-Trendli & $-5,873^{*}$ & $\mathrm{I}(0)$ \\
\hline & None & $-3,348 *$ & $\mathrm{I}(0)$ \\
\hline \multirow{3}{*}{$\begin{array}{l}\text { Ticari Kredi Faiz } \\
\text { Oranı (FO) }\end{array}$} & Sabitli & $-12,453^{*}$ & $\mathrm{I}(0)$ \\
\hline & Sabitli-Trendli & $-10,654^{*}$ & $\mathrm{I}(0)$ \\
\hline & None & $-16,453 *$ & $\mathrm{I}(0)$ \\
\hline \multirow{3}{*}{$\begin{array}{l}\text { Borsa İstanbul-100 } \\
\text { (BİST) endeksi }\end{array}$} & Sabitli & $-9,127^{*}$ & $\mathrm{I}(0)$ \\
\hline & Sabitli-Trendli & $-7,543 *$ & $\mathrm{I}(0)$ \\
\hline & None & $-5,234^{*}$ & $\mathrm{I}(0)$ \\
\hline \multirow{3}{*}{$\begin{array}{l}\text { Bankalar Arası } \\
\text { Gecelik Ortalama } \\
\text { Faiz Oranı }\end{array}$} & Sabitli & $-11,398^{*}$ & $\mathrm{I}(0)$ \\
\hline & Sabitli-Trendli & $-3,233^{*}$ & $\mathrm{I}(0)$ \\
\hline & None & $-17,297^{*}$ & $\mathrm{I}(0)$ \\
\hline \multirow{3}{*}{$\begin{array}{l}\text { Enflasyon= Tüfe } \\
\text { Değişim Hızı }\end{array}$} & Sabitli & $-11,654 *$ & $\mathrm{I}(0)$ \\
\hline & Sabitli-Trendli & $-5,912 *$ & $\mathrm{I}(0)$ \\
\hline & None & $-18,109 *$ & $\mathrm{I}(0)$ \\
\hline \multirow{3}{*}{$\begin{array}{l}\text { Parasal Büyüklük= } \\
\text { Parasal Taban/ TUFE }\end{array}$} & Sabitli & $-8,453 *$ & $\mathrm{I}(0)$ \\
\hline & Sabitli-Trendli & $-5,432 *$ & $\mathrm{I}(0)$ \\
\hline & None & $-3,458 *$ & $\mathrm{I}(0)$ \\
\hline \multirow{3}{*}{ İşsizlik Oranı, } & Sabitli & $-4,654^{*}$ & $\mathrm{I}(0)$ \\
\hline & Sabitli-Trendli & $-5,578 *$ & $\mathrm{I}(0)$ \\
\hline & None & $-17,102 *$ & $\mathrm{I}(0)$ \\
\hline
\end{tabular}

Not: *, \%1 seviyesinde anlamlılığı ifade etmektedir. 
Im, Pesaran, Shin (2003) ve Levin, Lin, Chu (2002) birim kök testlerinin sonuçları incelendiğinde tüm değişkenlerin ilgili düzeyde durağan oldukları anlaşılmaktadır. İlgili modelde değişkenler durağan düzeyde olduklarının tespitinden sonra Havuzlanmış En Küçük Kareler (HEKK Pooled OLS, Klasik Model) modelinin panel sonuçları Tablo 5'te yer almaktadır. Öncelikli olarak modelde otokorelasyon ve homoskedastik (sabit varyans) poroblemlerinin olup olmadiğı test edilmelidir. Otokorelasyon testi için Durbin-Watson (D-W İst.) ve Baltagi-Wu LBI testleri kullanılmış olup test sonuçları aşağıda yer almaktadır.

Tablo 5'te oto korelasyon testi sonuçlarına bakıldığında test istatistik sonuçları 2'den küçük olmas1 oto korelasyon sorunu olduğunu ifade etmektedir. İlgili modelde otokorelasyon sorununun giderilmesinde AR(1) kalıntı değeri kullanılarak oto korelasyonun varlığg sinanmaktadır. Modelde birimlere göre değişen varyans sorununun olup olmadığını test etmek için, wald testi yapılmaktadır. Wald testinde ilgili hipotez aşağıda yer almaktadır.

$h_{0}=$ Varyanslar, birimlere göre homoskedastiktir.(sabit varyans)

Tablo 5’te değiştirilmiş wald testi Sonucuna bakıldığında, test sonucuna göre, Ho hipotezi \%1 anlamlılık düzeyinde kabul edilmiş olup ve modelin sabit varyans varsayımı sağlamadığı görülmüştür. Değişen varyans problemlerinin giderilmesi amacıyla White cross-section düzeltmesi yapılmıştır. İlgili düzeltmeler yapıldıktan sonra panel regresyon analizinin tahmin sonuçları Tablo 5 'teyer almaktadır.

Tablo 5: Oluşturulan Modele İlişkin Parametre Tahmin Sonuçları

\begin{tabular}{|c|l|l|l|l|}
\hline Sembol & Değisskenler & Katsayı & t İstatistiği & $\begin{array}{l}\text { Standart } \\
\text { Hata }\end{array}$ \\
\hline AR(1) & & 0,244 & $3.216(0.000)$ & 0.005 \\
\hline B1 & Reel Efektif Faiz Oran1, & 0,345 & $4.456(0.002)$ & 0.012 \\
\hline B2 & Aktif Kârlılığ1, & $-0,234$ & $3.456(0.062)$ & 0.033 \\
\hline B3 & Aktif Büyüklüğü, & $-0,102$ & $3,664(0.000)$ & 0.002 \\
\hline B4 & Türk Parası Kredilerinin Pay1, & 0,468 & $2,136(0.001)$ & 0.201 \\
\hline B5 & Mevduatın Krediye Dönüşüm Oran1, & $-0,433$ & $5,222(0.003)$ & 0.022 \\
\hline B6 & Sermaye Yeterlilik Rasyosu & 0,165 & $5,992(0.002)$ & 0.011 \\
\hline B7 & Özsermaye Kârlılı̆ı, & 0,045 & $2,669(0.042)$ & 0.013 \\
\hline B8 & Kredi Büyüme Oran1, & 0,065 & $4,458(0.002)$ & 0.010 \\
\hline B9 & Tüketici Kredilerinin Pay1 & 0,031 & $5,678(0.004)$ & 0.020 \\
\hline M1 & Gayri Safi Yurt İçi Hasıla (GSYİH), & $-0,083$ & $5,668(0.000)$ & 0.027 \\
\hline M2 & Reel Döviz Kuru (RDK), & 0,035 & $5.764(0.003)$ & 0.082 \\
\hline M3 & Ticari Kredi Faiz Oranı (FO) & $-0,134$ & $3.627(0.002)$ & 0.053 \\
\hline M4 & Borsa İstanbul-100 (BİST) endeksi & $-0,087$ & $5.396(0.054)$ & 0.044 \\
\hline M5 & Bankalar Arası Gecelik Ortalama Faiz Oranı & 0,543 & $5,456(0.002)$ & 0.032 \\
\hline M6 & Enflasyon= Tüfe Değişim Hız1 & 0,165 & $3,227(0.001)$ & 0.011 \\
\hline M7 & Parasal Büyüklük= Parasal Taban/ TUFE & 0,156 & $2,199(0.004)$ & 0.026 \\
\hline M8 & İşsizlik Oranı, & $-0,554$ & $3,888(0.000)$ & 0.019 \\
\hline$R^{2}$ & & & 0.764 & \\
\hline Düzeltilmiş $R^{2}$ & & 0.798 & \\
\hline F istatistiği & & $279.853(0.000)$ & \\
\hline D-W istatistiği & & 1.979 & \\
\hline Baltagi-Wu LBI & & 1.898 & \\
\hline Değiştirilmiş Wald Testi Sonucu & & $43.665(0.000)$ & \\
\hline Wooldridge istatistiği & & $1015.33(0.000)$ & \\
\hline
\end{tabular}

Not: Parantez içindeki değerler, olasılık değerlerini gösterir. 
Tablo 4'te F test istatistiği ve olasılık değerlerinin 279.853 (0.000)olduğu için istatistiki olarak $\% 5$ anlamlılık seviyesinde modelin anlamlı olduğu sonucuna ulaşılmaktadır. $R^{2}$ değeri 0.76 bir başka ifadeyle bankaya ya da makroekonomik parametrelerin sorunlu krediler üzerinde $\% 76$ açıklayabildiğini göstermektedir. Düzeltilmiş $R^{2}$ değerinde ise bağımlı değişkenlerin bağımsız değişkeni açıklama gücü $\% 79$ olduğu gözlemlenmiştir. Bağımsız değişkenlere ait t-istatistikleri ve olasılık değerlerinin her ikisinin de \%10 anlamlılık düzeyinde anlamlı olduğu gözlemlenmektedir.

Tablo 5'te oluşturulan regresyon modeline ilişkin parametre tahmin sonuçlarına bakıldığında GSYİH yani büyüme parametresinin sorunlu krediler üzerinde negatif etki yarattığı bir başka değişle olası durumda Türkiye'de ekonomi \%1 daraldığı durumda sorunlu kredilerde $\% 0,08$ civarında bir artış gözlemleneceği sonucu ortaya çıkmıştır. Bununda yanında döviz kuru sepetinde yaşanacak bir artış sorunlu kredileri arttıracağ 1 yani reel döviz kurunda yaşanan \%1 lik bir artış sorunlu kredileri \%0.03 arttıracaktır. Bunun yanında istatistiki sonuçlara bakıldığında aktif büyüklüğü ve BIST 100 endeksi parametreleri ile sorunlu krediler arasında istatistiki olarak anlamlı sonuçlara ulaşılamamıştır.

\section{Bulgular}

Ülkede ekonomik büyümenin sembolü olan GSYİH parametresi ile sorunlu krediler ile ters yönlü bir ilişkinin olduğu gözlemlenmiştir. Bunun yanında döviz kuru sepeti ile faiz oranları ile sorunlu krediler ile pozitif yönlü bir ilişki ortaya çıkmıştır. Bir başka ifadeyle olası döviz kurunda yaşanabilecek artış, ithalatı caydırıcı ihracatı özendireceği için ekonomik büyüme üzerinde olumlu etki yaratacaktır. Enflasyonist dönemlerde faiz oranlarında yaşanacak artış, hem kredi kullanma yönünde isteksizliği arttıracak bunun yanında ekonomide yaşanan bozulma sonucunda bankaların verdikleri kredilerin geri dönüşleri ile ilgili problemler sorunlu kredilerin artmasına neden olacaktır.

Çalışmadan elde edilen bulgular incelendiğinde reel faiz oranının birinci gecikmesi ile sorunlu krediler arasındaki ilişki derecesinin pozitif olduğu, bu durumun reel faiz oranının artması kredi maliyetini arttırdığı için, kredi geri ödemelerde güçlüklere neden olduğu ve bununda sorunlu kredileri arttırdığı gözlemlenmiştir.

Mevduatın krediye dönüşüm oranı ile sorunlu krediler arasında ilişki derecesi ve yönüne bakıldığında bu ilişki derecesinin negatif olduğu gözlemlenmiştir. Bu oran bankalar açısında çok büyük önem arz eden bir oran olup aynı zamanda kredi büyüme hızını da ifade etmektedir.

İşsizlik oranı ile sorunlu krediler arasında ilişki derecesi ve yönüne bakıldığında bu ilişki derecesinin pozitif olduğu gözlemlenmiştir. Bu durum özellikle işsizlik oranının artması sonucunda, işsiz kalanların ödeme gücünü yitirmesi sonucunda kredisini ödemekte güçlük çektiği ve bunun sonucunda bankaların sorunlu kredi oranlarını arttırdığı ve sorunlar oluşmaya başladığı gözlemlenmiştir.

Tüketici kredilerini payı ile sorunlu krediler arasında ilişki derecesi ve yönüne bakıldığında bu ilişki derecesinin pozitif olduğu gözlemlenmiştir. Mevcut krediler içerisinde tüketici kredileri payının büyük olması bu değişkenin önemini ortaya koymaktadır. Bu durum mevcut konjonktürel yapıyı yansıtması açısında anlamlı sonuçlar vermektedir. Tüketici kredilerde yaşanabilecek artış, mevcut kredilerin geri ödenme riskini arttırdığı için sorunlu kredileri de arttıracaktır.

Enflasyon oranı ile sorunlu krediler arasında ilişki derecesi ve yönüne bakıldığında bu ilişki derecesinin pozitif olduğu gözlemlenmiştir. Özellikle mevcut dönemde Türkiye'de yaşanan ekonominin durgun olduğu bu dönemlerde enflasyonda yaşanan artı̧̧ bankacılık sektörü üzerinde negatif etki yaratmaktadır. $\mathrm{Bu}$ durum özellikle kredilerin geri dönüşünde problemlere neden olmaktadir.

Sermaye yeterlilik rasyosu ile sorunlu krediler arasında ilişki derecesi ve yönüne bakıldığında bu ilişki derecesinin pozitif olduğu gözlemlenmiştir. Genel literatür açısından değerlendirildiğinde genellikle ilişki derecesinin yönünün ne olması gerektiği hakkında genel oluşmuş bir görüş 
bulunmamaktadır. Yapılan çalışmalarda ilişki yönünü hem pozitif hem de negatif bulan çalışmalar mevcut olsa da, sermayesi güçlü olan bankaların sorunlu kredilerden etkilenme derecelerinin düşük olabileceği ifade edilebilir.

Banka aktif büyüklüğü ve ülkedeki olumlu ve olumsuz gelişmeleri hızlı bir şekilde yansıtan BIST 100 endeksi ile sorunlu krediler arasında ilişki derecesi ve yönüne bakıldığında bu ilişki derecesinin negatif olduğu gözlemlenmiştir. Bu durum BIST 100 endeksinde yaşanabilecek artış ya da azalışların sorunlu krediler üzerinde etkili olabileceği sonucunu ortaya koymaktadır.

Öz sermaye karlılığı ve aktif karlılığı bağımsız değişkenlerin ise bağımsız değişken sorunlu krediler arasında ilişki derecesi ve yönüne bakıldığında bu ilişki derecesinin istatistiki olarak anlamlı sonuçlar vermediği gözlemlenmiştir.

\section{Sonuç}

Ekonominin temel lokomotifi olan bankaların temel amaçları mevduat toplamak ve topladıkları mevduatları kredi olarak ihtiyaç sahiplerine kullandırarak, bu kredilerin sorunsuz bir şekilde geri dönmesini beklerler. Ekonomin durgun olduğu dönemlerde enflasyon ve faiz oranları gibi çeşitli parametrelerde yaşanan artış sonucunda zor durumda kalan kredi kullanıcıları bankalara olan ödemelerini geciktirmekte veya ödeyememektedir. Bu durum bankaların faaliyetlerini riskli bir duruma getirerek sorunlu kredilerini arttırmaktadır. 2008 küresel finansal kriz ve sonrasında Türkiye'ye özgü politik, siyasi ve jeopolitik risk gibi unsurlar sonucunda riskin devam ettiği ve bankaların kredilendirme politikalarında başarısızlıkları sorunlu krediler konusunun geçmişte olduğu gibi günümüzde de ne kadar önemli olduğunu ortaya koymaktadır. Bundan dolayı sorunlu krediler ülkelerin ekonomik yapısı ve işleyişi açısından oldukça önemlidir. Özellikle Türkiye'de 2015 yılında itibaren sorunlu kredilerin hacmi gün geçtikçe artan bir şekilde devam ettiği gözlemlenmektedir. 2019 mart ayı itibariyle 106 milyar TL boyutuna ulaşmıştır. Özellikle 2018 yılında ekonomik durgunluk dönemlerinde şirketlerin konkordato taleplerinde yaşanan artış ve bu süreçte bankaların kondordato talep eden firmalardan alacaklarını tahsil edilebilirliğini düşürmesi sonucunda sorunlu kredilerin en üst seviyesine ulaşmasına imkân kılmıştır.

Türk bankacıllk sektöründe 2005-2018 yılları arasında faaliyetlerini sürdüren 25 ticari bankanın istikrarsızlığın göstergesi olan sorunlu kredileri etkileyen bankaya özgü ve makro parametrelerin neler olabileceğini ortaya koyulmaya çalışılmıştır. Çalışmada ilgili değişkenlerin sorunlu krediler ile ilişki derecesi ve yönü panel veri analizi ile ele alınmıştır. Panel veri modeli, Havuzlanmış En Küçük Kareler (HEKK - Pooled OLS, Klasik Model), Sabit Etkiler (Fixed Effects) ve Rassal Etkiler (Random Effects) yaklaşımlarından biri kullanılarak tahmin edilmektedir. Çalışmada kurulan modeli istatistiki olarak en iyi ifade edebilecek yaklaşımın Havuzlanmış En Küçük Kareler (HEKK - Pooled OLS, Klasik Model) yöntemi olduğu tespit edilmiştir.

Panel veri analizi sonucunda Reel Efektif Faiz Oranı, Aktif Büyüklüğ̈̈, Türk Parası Kredilerinin Payı, Mevduatın Krediye Dönüşüm Oranı, Sermaye Yeterlilik Rasyosu, Kredi Büyüme Oranı, Tüketici Kredilerinin Pay1, Gayri Safi Yurt İçi Hasıla (GSYIH), Reel Döviz Kuru (RDK), Ticari Kredi Faiz Oranı (FO), Bankalar Arası Gecelik Ortalama Faiz Oranı, enflasyon, parasal büyüklük, ve işsizlik oranı ile sorunlu krediler arasında ilişkinin istatistiki olarak anlamlı olduğu fakat aktif kârlılığı,BIST100 ve öz sermaye kârlılığı ile anlamlı sonuçlar vermediği tespit edilmiştir.

Çalışmanın daha önceki literatür çalışmalarına bakıldığında sorunlu krediler ile ilişkili olabilecek bu kadar değişkenin ele alındığı çalışmanın olmayışı çalışmanın özgünlüğünü ortaya koymaktadir. 


\section{KAYNAKÇA}

Adela, S., \& Iulia, I. (2010). Study of Correlation Between Average Interest Rate and NonPerforming Loans In The Romanian Banking System During 2006-February 2010. The Journal of the Faculty of Economics, 2, 777-782.

Altunöz, U. (2018). Sorunlu Krediler Bağlamında Türk Bankacılığında Kredi Kayıp Karşılığının Makroekonomik Değişkenlere Etkisi: Panel Data Ve Zaman Serileri Analizi. Hitit Üniversitesi Sosyal Bilimler Enstitüsü Dergisi, 11(1), 63-82.

Baltagi, B. (2001). Econometric Analysis of Panel Data (Third Edition). UK: John Wiley \& Sons Ltd.

BALTAGİ, B. (2013). Econometric Analysis of Panel Data (5. Edition),. London: John Wiley \& Sons Ltd.

Baltagi, B. H. (2005). Econometric analysis of panel data, 3rd ed. John Wiley and Sons Ltd.

BBDK. (2007). Sermaye Ölçümü ve Sermaye Standartlarının Uluslararası Düzeyde Uyumlaştırılması. BBDK.

Beck, R., Jakubik, P., \& Piloiu, A. (2013). Non-Performing Loans What Matters In Addition to The Economic Cycle. European Central Bank.

Bilman, A. S. (2014). Ticari Açıklık Büyüme Etkileşimi: Panel Veri Analizi ve Ülkelerarası Karş1laştırma (Interaction between Trade Openness and Growth: Panel Data Analysis and Comparison between Countries). Doctoral Thesis, 169. İzmir: Dokuz Eylül University, Department of Economics.

Boudriga, A., Boulila, N., \& Jellouli, S. (2009). Does Bank Supervision Impact Nonperforming Loans: Cross Country Determinants Using Agregate Data. MPRA.

Dickey, D. A. (1981). "Likelihood Ratio Statistics for AutoregressiveTime Series with a Unit Root (Cilt 49). Econometrica.

Fofack, H. (2005). Nonperforming Loans in Sub-Saharan Africa: Causal Analysis and Macroeconomic Implications. World Bank Policy Research.

Greene, W. (2012). Econometric analysis (7th Ed.). New Jersey: Prentice Hal.

Greene, W. H. (2003). Econometric Analysis (5. Edition). New Jersey: Prentice Hall.

Greenidge, K., \& Grosvenor, T. (2010). Forecasting Non-Performing Loans In Barbados. Business, Finance and Economics In Emerging Economies, 5(5), 80.

Hsiao, C. (2002). Analysis of Panel Data (2. Edition). New York: Cambridge University Press.

IMF. (2010). Financial Soundness Indicators: Compilation Guide. 06 03, 2019 tarihinde https://www.imf.org/external/pubs/ft/fsi/guide/2006/pdf/fsiFT.pdf:

https://www.imf.org/external/pubs/ft/fsi/guide/2006/pdf/fsiFT.pdf adresinden alınd1

Klein, N. (2013). Non-Performing Loans in CESEE: Determinants and Macroeconomic Performance. International Monetary Fund.

Levin, A. L. (2002). Asymptotic and finitesample properties. Journal of Econometrics, 108, 1-24.

Mavili, P. T. (2008). Ticari Bankacıllkta Sorunlu Krediler ve Yönetimi. Sosyal Bilimler Enstitüsü, Basılmamış Yüksek Lisans Tezi. İzmir : Dokuz Eylül Üniversitesi.

Messai, A. S., \& Jouini, F. (2013). Micro and Macro Determinants of Non-Performing Loans. International Journal of Economics and Financial Issues, 3(4), 852-854. 
Mileris, R. (2014). Macroeconomic Factors of Non-Performing Loans in Commercial Banks. Ekonomika, 93(1), 27.

Nkusu, M. (2011). onperforming Loans and Macrofinancial Vulnerabilities in Advanced Economie. International Monetary Fund.

OECD. (2010). Competition, Concentration and Stability in The Banking Sector. OECD.

Önder, K. (2017). Pamuk Arzını Etkileyen Faktörlerin Panel Veri ile Analizi. Eskişehir Osmangazi Üniversitesi İ̈BF Dergisi, 12(1), 83- 98.

Podpiera, J., \& Weill, L. (2007). Bad Luck or Bad Management? Emerging Banking Market Experience. Czech National Bank.

Roy, S. G. (2014). Determinants of Non-Performing Assets in India. Eurasian Journal of Economics and Finance, 2(3), 69-78.

Stanley, M. (2013). FX Pulse. Morgan Stanley Reaserch Report: (http://www.morganstanleyfa.com/public/projectfiles/dce4d168-15f9-4245-9605e37e2caf114c.pdf) adresinden alınd1

Şahbaz, N. (2010). Türk Bankacılık Sektöründe Sorunlu Krediler ve Makroekonomik Etkileri: Türkiye Örneği. Afyon Kocatepe Üniversitesi, Sosyal Bilimler Enstitüsü, Basılmamış Yüksek Lisans Tezi. Afyonkarahisar.

Torun, M., \& Altay, E. (2019). Ticari Bankacılık Sektöründe Sorunlu Kredileri Etkileyen Faktörlerin Analiz. Yönetim ve Ekonomi Araştırmaları, 179-200.

Wooldridge, J. (2009). Introductory econometrics: a modern approach (4th. Ed.). Canada: South Western Cengage Learning.

Yahaya, K. A., \& Oni, O. O. (2016). Impact of MacroEconomic Factors on NonPerforming Loans in the Nigerian Deposit Money Banks. Amity Global Business Review, 70. 